\title{
EVALUASI USABILITY PADA APLIKASI E-LEARNING DI JURUSAN TEKNIK INFORMATIKA UNIVERSITAS PAMULANG
}

\author{
Thoyyibah T. ${ }^{1}$ \\ ${ }^{1}$ Teknik Informatika, Fakultas Teknik \\ Universitas Pamulang \\ dosen01116@unpam.ac.id
}

\begin{abstract}
ABSTRAK
Universitas Pamulang merupakan salah satu kampus swasta yang telah melaksanakan sistem pembelajaran secara online. Pada sistem pembelajaran online ini atau yang disebut dengan e-learning, terdapat banyak aktivitas antara dosen dan mahasiswa di antaranya diskusi online dan sharing data. Kegiatan e-learning ini tidak terbatas oleh tempat dan waktu. Namun, pada kenyataannya terdapat beberapa mahasiswa yang tidak melakukan e-learning. Tujuan penelitian ini yaitu melakukan evaluasi usability untuk meningkatkan kepuasan user dalam menggunakan e-learning. Metode penelitian ini yaitu studi pustaka, studi lapangan dan kuesioner SUMI (Software Usability Measurement Inventory). Kuesioner dilakukan terhadap 20 responden, diantanya 10 mahasiswa dan 10 dosen teknik informatika. Kuesioner dilakukan dengan 3 kategori yaitu efektivitas, efisiensi dan kepuasan dengan masing-masing 10 soal sehingga terdapat 60 pertanyaan dan 3 linker yaitu 4 jika setuju semua, 2 jika tidak tahu dan 0 tidak setuju. Hasil perhitungan kuesioner SUMI terhadap e-learning teknik informatika yaitu $92.5 ; 87.5 ; 75 ; 90 ; 90 ; 75$. Hasil evaluasi usability berada di atas rata-rata artinya usability pada sistem E-learning teknik informatika UNPAM sudah masuk kategori baik.
\end{abstract}

Kata Kunci: e-learning, evaluasi usability, SUMI (Software Usability Measurement Inventory)

\begin{abstract}
Pamulang University is one of the private campus that has implemented online learning system. In this online learning system or called e-learning, there are many activities between lecturers and students such as online discussion and data sharing. This e-learning activity is not limited by time and place. However, in reality there are some students who do not do e-learning. The purpose of this study is to evaluate usability to improve user satisfaction in using e-learning. This research method is literature study, field study and questionnaire SUMI (Software Usability Measurement Inventory). Questionnaires were conducted on 20 respondents, including 10 students and 10 lecturers of informatics engineering. Questionnaires were conducted with 3 categories of effectiveness, efficiency and satisfaction with each 10 questions so there are 60 questions and 3 linkers that is 4 if all agree, 2 if not know and 0 disagree. Results of calculation of SUMI questionnaire to e-learning informatics technique that is $92.5 ; 87.5 ; 75 ; 90 ; 90 ; 75$. The result of usability evaluation is above average means usability on E-learning system of informatics engineering UNPAM has been categorized well.
\end{abstract}

Keywords: e-learning, usability evaluation, SUMI (Software Usability Measurement Inventory)

http://dx.doi.org/10.15408/jti.v11i2.8036 


\section{PENDAHULUAN}

E-learning merupakan sistem pembelajaran online tanpa mengenal tempat dan waktu. Di samping itu e-learning merupakan sistem pembelajaran elektronik yang mencakup berbagai jenis media yang dapat memberikan dan menampilkan teks, audio, gambar, animasi, dan video streaming, dan termasuk aplikasi teknologi dan proses seperti audio atau video tape, TV satelit, CDROM, dan pembelajaran berbasis komputer, baik menggunakan intranet, extranet atau berbasis website [1]. Dilain sisi E-learning (electronic learning) merupakan salah satu cara untuk menyampaikan materi pembelajaran secara efektif. Inovasi dalam $e$ learning teknologi mengarah ke sebuah revolusi di bidang pendidikan, yang memungkinkan belajar menjadi individual (pembelajaran adaptif), meningkatkan interaksi peserta didik dengan orang lain (pembelajaran kolaboratif), dan mengubah peran pengajar [2]. Sehingga E-learning digunakan untuk menyampaikan materi pembelajaran yang memenuhi kebutuhan individual siswa [3]. Dengan e-learning juga siswa bisa berfikir tinggi yang mampu menghubungkan informasi yang lama dengan informasi yang baru untuk memecahkan suatu permasalahan yang dihadapi [4].

Namun kenyataanya masih terdapat beberapa mahasiswa tidak melakukan $e$ learning. Sehingga sangat diperlukan usability terhadap sistem e-learning. Usability merupakan penilaian terhadap tingkat kebergunaan suatu sistem. Usability ini menggunakan kuesioner SUMI (Software Usability measurement Inventory). Dengan adanya kuesioner ini bisa menjadi tolak ukur atau bisa diketahui kecenderungan sikap penolakan serta penerimaan terhadap aplikasi sehingga bisa memberikan masukan untuk penyempurnaan aplikasi dikemudian hari [5].

\section{TINJAUAN PUSTAKA}

\subsection{Sejarah Universitas Pamulang}

Universitas Pamulang didirikan pada tahun 2000 oleh Yayasan Prima Jaya yang diketuai oleh Drs. Wayan. Namun karena ketidakmampuan Yayasan Prima Jaya dalam mengelola suatu Universitas, maka merekapunmengalihkan kepemilikan dan pengelolaannya kepada Yayasan Sasmita Jaya pada awal tahun 2005. Setelah berganti manajemen, maka berganti pulalah tujuan yang ingin dicapai Universitas Pamulang. Tujuan dari yayasan Sasmita Jaya adalah mewujudkan suatu sarana pendidikan yang murah dan terjangkau oleh seluruh lapisan masyarakat tanpa melupakan kualitas dari pendidikan itu sendiri. Oleh karena itu Universitas Pamulang selalu mengangkat tenaga pengajar dan staff administrasi yang berkompeten di bidangnya. Kamipun juga melakukan pengembangan dibidang kurikulum yang disesuaikan dengan kebutuhan dunia kerja, sehingga seluruh lulusan Universitas Pamulang diterima dengan baik dalam dunia kerja. Selain itu untuk menunjang kegiatan perkuliahan, Universitas Pamulang telah menyediakan berbagai macam fasilitas seperti laboratorium dan perpustakaan. Dengan terselenggaranya pendidikan murah di Universitas Pamulang, kami selaku pihak Yayasan Sasmita Jaya berharap semua lapisan masyarakat di Indonesia dapat menikmati pendidikan di bangku kuliah. Dengan terdidiknya seluruh lapisan masyarakat Indonesia maka secara otomatis pun itu akan menurunkan tingkat kebodohan dan kemiskinan serta meningkatkan daya jual dan harga diri masyarakat Indonesia.

\subsection{Sistem}

Definisi sistem menurut buku sistem teknologi informasi sebagai kumpulan dari komponen yang saling berhubungan satu dengan yang lain yang membentuk satu kesatuan untuk mencapai satu tujuan tertentu. Dapat dilihat dari dua kelompok pendekatan yaitu yang menekankan pada prosedur dan yang menekankan pada komponen atau elemennya. Pendekatan sistem yang lebih menekankan pada prosedur mendefinisikan sistem sebagai suatu jaringan kerja dari prosedur-prosedur yang saling berhubungan, berkumpul bersama untuk melakukan sesuatu kegiatan atau untuk menyelesaikan suatu sasaran yang tertentu [6].

Pendekatan sistem yang lebih menekankan pada komponen pada komponen atau elemennya definisikan sistem sebagai kumpulan dari elemen-elemen yang berinteraksi untuk mencapai suatu tujuan tertentu [6]. Dari definisi-definisi diatas, penulis dapat menyimpulkan sebagai berikut: "Sistem adalah jaringan kerja dengan segala aktifitas yang saling terkait yang dilakukan 
oleh objek yang saling berhubungan dalam suatu wadah yang sama untuk mencapai suatu tujuan atau sasaran yang telah ditentukan".

Sistem dapat diklasifikasikan dari beberapa sudut pandangan, di antaranya adalah sebagai berikut:

1) Sistem diklasifikasikan sebagai sistem abstrak (abstrack system) dan sistem fisik (phisycal system). Sistem abstrak adalah sistem yang berupa pemikiran atau ide_ide yang tidak tampak secara fisik. Sistem fisik meruakan sistem yang ada secara fisik.

2) Sistem diklasifikasikan sebagai sistem alamiah (natural system) dan sistem buatan manusia (human made system). Sistem alamiah adalah sistem yang terjadi melalui proses alam sedangkan sitem buatan manusia adalah yang dirancang oleh manusia.

3) Sistem diklasifikasikan sebagai sistem tertentu (determinetic system) dan sistem tertentu atau (probabilistic system). Sistem tertentu beroperasi dengan tingkah laku yang sudah dapat diprediksi sedangkan yang tak tentu sistem yang kondisi masa depannya tidak bisa diprediksi karena mengandung unsur probabilitas.

4) Sistem di klasifikasikan sebagai sistem tertutup dan sistem terbuka. Sistem terutup ialah sistem yang tidak berhubungan dengan lingkungan luar sedangkan yang terbuka adalah sistem yang berhubungan dan terpengaruh dengan lingkungan luar.

Informasi merupakan salah satu bagian terpenting dalam suatu organisasi, tanpa informasi suatu sistem menjadi tidak berjalan. Kualitas informasi ditentukan oleh bagaimana informasi tersebut memotivasi manusia untuk bertindak dan memberikan kontribusi (sumbangan) terhadap pembelian keputusan yang efeltif.

"Informasi adalah data yang diolah menjadi bentuk yang berguna bagi para pemakainya "[6]

Sistem informasi adalah kumpulan dari sub-sub sistem baik phisik maupun non phisik yang saling berhubungan satu sama dan bekerja sama secara harmonis untuk mencapai satu tujuan yaitu mengolah data menjadi informasi yang berguna.
Adapun tiga aktivitas yang terjadi pada sistem informasi adalah input, processing, output dan penjelasannya sebagai berikut:

a) Input adalah sekumpulan data mentah dalam organisasi maupun luar organisasi untuk diproses dalam suatu sistem informasi.

b) Processing adalah konversi atau pemindahan, manipulasi dan analisa input mentah menjadi bentuk yang lebih berarti bagi manusia.

c) Output adalah distribusi informasi yang sudah diproses ke anggota organisasi dimana output tersebut akan digunakan.

d) Informasi dalam hal ini juga membutuhkan umpan balik (feedback) yaitu output yang dikembalikan ke anggota organisasi yang berkepntingan untuk membantu mengevaluasi atau memperbaiki input.

\subsection{E-Learning}

Dibangunnya pembelajaran secara online, E-Learning atau pembelajaran elektronik merupakan proses yang memanfaatkan teknologi informasi dalam hal ini menggunakan media online seperti internet sebagai metode penyampaian, interaksi dan fasilitasi. E-Learning merupakan proses transfer pengetahuan melalui media komputer, jaringan komputer dan internet. Jenis Aplikasi e-learning berupa web, pendidikan virtual dan segala kontent digital baik berupa gambar, video dan animasi. Proses belajar secara $e$ learning mempunyai kelebihan yaitu tidak terikat waktu dan tempat [7]. E-learning memungkinkan belajar dan mengatur sebuah kelas tanpa harus bertatap muka secara langsung. Dengan adanya sistem manajemen pendidikan online, maka siswa akan mengevaluasi dirinya untuk lebih bersaing dengan pelajar lainnya [8]. E-Learning juga memberikan fasilitas kepada guru dan peserta didik untuk saling berinteraksi dalam lingkungan belajar melalui jejaring sosial online [9]. Pemanfaatan E-Learning diharapkan mampu meningkatkan kualitas pembelajaran, kualitas aktivitas serta kemandirian mahasiswa [10].

\subsection{Usability}

Menurut ISO 9241-11-1998 usability merupakan penilaian sejauh mana produk dapat digunakan oleh pengguna dengan ukuran efektivitas, efisiensi dan kepuasan dalam 
konteks penggunaan. Di samping itu usability testing adalah salah satu metode yang digunakan pengguna untuk melihat tingkat kemudahan pengguna dalam berinteraksi dengan sebuah sistem informasi [10]. Untuk mengukur kepuasan aplikasi, maka digunakanlah kuesioner SUMI (Software Usability Measurment Inventory), Kuesioner yang dikembangkan oleh Universitas Collage Cork [12].

Usability merupakan interaksi antara media dengan pemakai [13]. Perencanaan Tahap awal sistem menggunakan usability dan interface untuk pemakai [14]. Usability dapat dilihat sebagai salah satu kriteria untuk memastikan tingkat baik dan buruknya suatu produk dan masalah pada usability disebabkan oleh kekurangan pengetahuan yang sering teridentifikasi pada saat pertama kali menggunakan sistem [15]. Usability produk software telah menjadi faktor kunci kualitas software [16].

Usability adalah salah satu bagian yang terpenting untuk mengetahui karakteristik dari kualitas sebuah sistem [17]. Di sisi lain usability sebagai atribut kualitas yang menilai seberapa mudah user interface digunakan, sehingga memungkinkan user untuk mengembangkan tugas secara jelas, transparan, dan bermanfaat [18].

\subsection{Penelitian Terkait}

Terdapat beberapa penelitian terdahulu yang digunakan sebagai acuan Usability Engineering diantaranya:

a. Penelitian yang berjudul Pengujian Usability untuk Meningkatkan Antarmuka Aplikasi Mobile, membahas tentang pengujian usability pada aplikasi anak-anak dengan menggunkan metode field observation yaitu dengan cara mengobsevasi pengguna bagaimana mereka menggunakan aplikasi. Komponen yang diuji berupa komponen efektivitas, efisiensi dan kepuasan. Hasil uji menunjukkan bahwa metode observasi langsung pada anak-anak dapat meningkatkan nilai usability M-Breakfast Nutrition dari $78,4 \%$ menjadi $91.1 \%$ sehingga diharapkan aplikasi dapat sesuai dengan tujuan agar dapat diterima oleh pengguna [19].

$b$. Penelitianm yang berjudul Penerapan Metode Usability Testing pada Evaluasi Situs Web Pemerintah kota Prabumulih, membahas tentang seberapa jauh kesalahan yang dibuat oleh pengguna dan mengukur isi situs web berdasarkan penduan penyelenggaraan situs web pemerintahan daerah yang dikeluarkan oleh Kementrian Komunikasi Republik Indonesia tahun 2003. Hasil penelitian ini juga menunjukkan bahwa $100 \%$ learnability, effeciency $66.66 \%$, memorability $58.33 \%$, satisfaction $53.33 \%$ yang mampu digunakan oleh pengguna [20].

c. Penelitian yang berjudul Pengukuran Tingkat Ketergunaan (Usability) Sistem Informasi Keuangan Studi Kasus: Duta Wacana Internal Transaction (DuWIT), membahas tentang seberapa besar tingkatan pemahaman dan kesulitan user dalam menggunakan sistem transaksi melalui aplikasi DuWIT. Hasil penelitian ini menunjukkan usability di atas $72 \%$ sehingga aplikasi ini dinyatakan user friendly [21].

\section{METODOLOGI}

Metode penelitian yang dilakukan penulis pada penelitian ini diantaranya:

\section{a. Studi Pustaka}

Pengumpulan data dengan
menggunakan atau mengumpulkan
sumber-sumber tertulis, dengan cara
membaca, mempelajari dan mencatat hal-
hal penting dari buku dan jurnal yang
berhubungan dengan masalah yang sedang
dibahas guna memperoleh gambaran
secara teoritis yang dapat menunjang pada
penyusunan penelitian.

\section{b. Studi Lapangan}

Studi lapangan adalah metode pengumpulan data dengan cara pengamatan langsung e-learning sebagai pada objek penelitian untuk mendapatkan data-data serta hal-hal penting yang berhubungan dengan e-learning, sehingga diperoleh data yang lengkap dan akurat.

c. Kuesioner

Untuk mengukur kepuasan aplikasi, maka digunakanlah kuesioner SUMI (Software Usability Measurment Inventory), Kuesioner yang dikembangkan oleh universitas Collage Cork [12].

\section{HASIL DAN PEMBAHASAN}

Evaluasi antarmuka detail pada Aplikasi E-Learning di Jurusan Teknik Informatika Universitas Pamulang dilakukan oleh Pada Dosen dan Mahasiswa sebanyak 20 responden. 
Penelitian ini menggunakan kuesioner yang diadopsi dari SUMI (Software Usability Measurement Inventory). Tujuan melakukan kuesioner yaitu untuk mengevaluasi sistem $E$ Learning, mengukur usability serta dapat menjadi media pembelajaran bagi pengguna terhadap aplikasi yang akan digunakan. Usability merupakan sebuah konteks penggunaan aplikasi dengan ukuran efektivitas, efisiensi dan kepuasan sehingga dapat mengukur sejauh mana suatu aplikasi dapat digunakan dengan mudah. Petunjuk Pengisian kuesioner yaitu:

1. Lembar kuesioner ini berisi 30 pertanyaan mengenai usability pengguna dalam mengakses Aplikasi E-Learning di Jurusan Teknik Informatika Universitas Pamulang Pada Dosen dan Mahasiswa sebanyak 20 responden, dengan ketentuan 10 dosen dan 10 mahasiswa.

2. Nomor responden harap diganti dengan mahasiswa atau dosen.

3. Beri tanda cek $(\sqrt{ })$ pada kolom yang telah disediakan yang paling mencerminkan pilihan Anda dengan pilihan setuju (S), tidak tahu (TT) dan tidak setuju (TS).

Kuesioner dilakukan terhadap e-learning teknik informatika UNPAM. Perhitungan Pada kuesipner SUMI dilakukan dengan kategori S, TT, IS dimana S (setuju) dikali 4, TT (tidak tahu) dikali 2, dan TS (tidak setuju) dikali 0 .

Hasil perhitungan Median Efektivitas, Efisiensi dan kepuasan bagi dosen dan mahasiswa terlihat pada Tabel 2, Tabel 3, Tabel 4, Tabel 5, Tabel 6, Tabel 7. Gambar 1 merupakan halaman utama e-learning. Gambar 2 merupakan tampilan mata kuliah E-learning. Pada gambar tersebut terdapaat beberapa mata kuliah yan diampu oleh dosen yang bersangkutan. Gambar 3 adalah tampilan dokumen download, gambar ini terdapat dokumen yang diap diunduh oleh mahasiswa. Gambar 4 yaitu tampilan forum diskusi, dosen akan mengawali membuat pertemuan dan pertanyaan yang akan didiskusikan. Hasil diskusi oleh dosen dan mahasiswa dapat terlihat pada Gambar 5.

Tabel 1. Kategori Efektivitas Dosen

\begin{tabular}{|c|c|c|c|c|c|c|c|c|c|}
\hline \multicolumn{10}{|c|}{ Kategori Efektivitas Dosen } \\
\hline 1 & 2 & 3 & 4 & 5 & 6 & 7 & 8 & 9 & 10 \\
\hline 30 & 75 & 75 & 75 & 90 & 95 & 100 & 100 & 100 & 100 \\
\hline
\end{tabular}

Tabel 2. Kategori Efisiensi Dosen

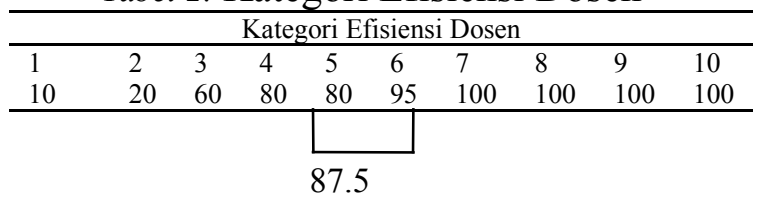

Tabel 3. Kategori kepuasan dosen

\begin{tabular}{|c|c|c|c|c|c|c|c|c|c|}
\hline \multicolumn{10}{|c|}{ Kategori Kepuasan Dosen } \\
\hline 1 & 2 & 3 & 4 & 5 & 6 & 7 & 8 & 9 & 10 \\
\hline 30 & 50 & 60 & 70 & 75 & 75 & 90 & 100 & 100 & 100 \\
\hline
\end{tabular}

Tabel 4. Kategori efektivitas mahasiswa

\begin{tabular}{llllllllll}
\hline \multicolumn{10}{c}{ Kategori Efektivitas Mahasiswa } \\
\hline 1 & 2 & 3 & 4 & 5 & 6 & 7 & 8 & 9 & 10 \\
45 & 60 & 70 & 80 & 90 & 90 & 95 & 95 & 100 & 100 \\
\hline
\end{tabular}

90

Tabel 5: Kategori efisiensi mahasiswa

\begin{tabular}{llllllllll}
\hline \multicolumn{10}{c}{ Kategori Efisiensi Mahasiswa } \\
\hline 1 & 2 & 3 & 4 & 5 & 6 & 7 & 8 & 9 & 10 \\
60 & 60 & 60 & 90 & 90 & 90 & 80 & 100 & 100 & 100 \\
\hline
\end{tabular}

\section{0}

Tabel 6. Kategori kepuasan mahasiswa

\begin{tabular}{|c|c|c|c|c|c|c|c|c|c|}
\hline \multicolumn{10}{|c|}{ Kategori Kepuasan Mahasiswa } \\
\hline 1 & 2 & 3 & 4 & 5 & 6 & 7 & 8 & 9 & 10 \\
\hline 45 & 60 & 60 & 70 & 70 & 80 & 80 & 85 & 90 & 100 \\
\hline
\end{tabular}




\section{OKTOBER 2018}
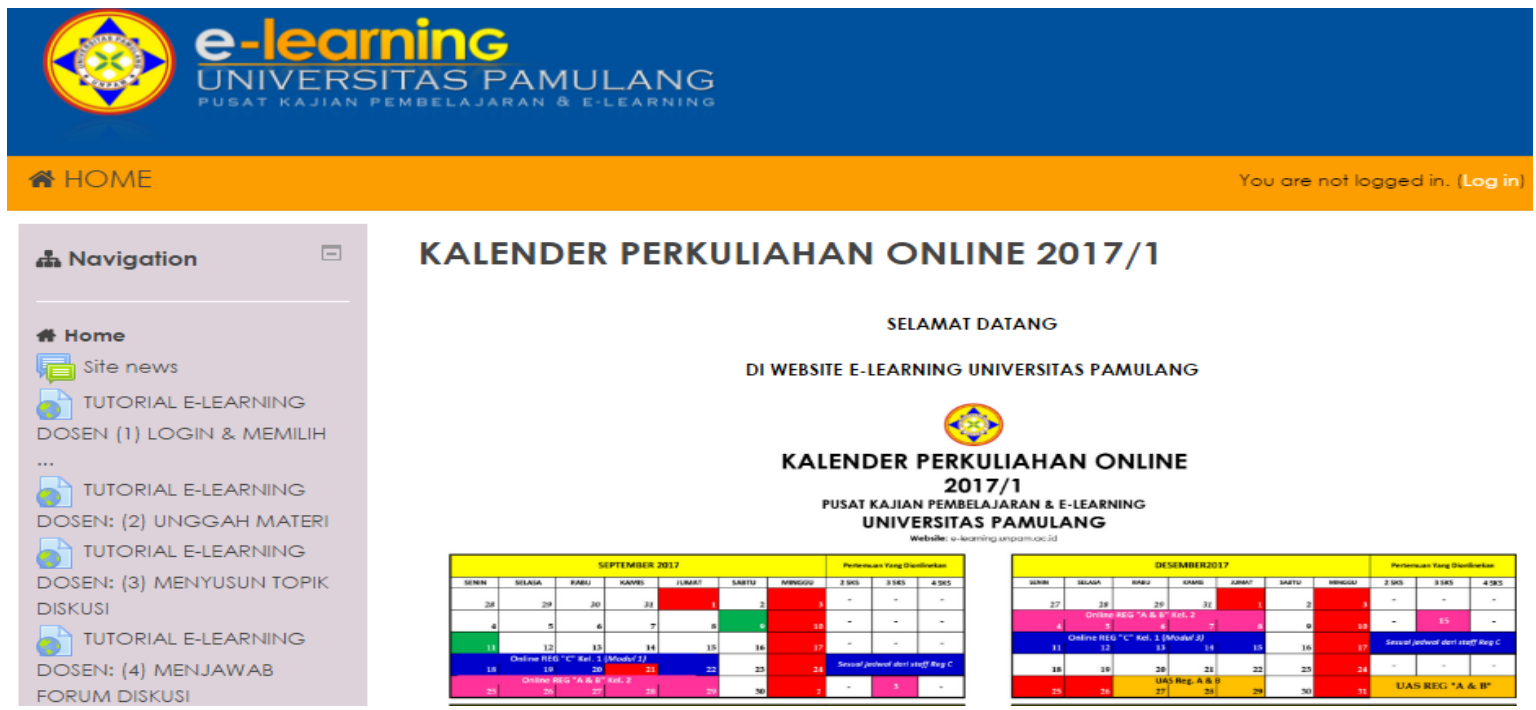

KALENDER PERKULIAHAN ONLINE 2017/1

SELAMAT DATANG

DI WEBSITE E-LEARNING UNIVERSITAS PAMULANG

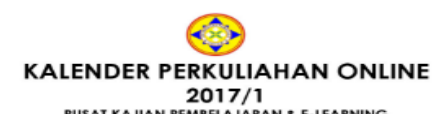

$2017 / 1$

PUSAT KAJIAN PEMBELAJARAN \& E-LEARNING
UNIVERSITAS PAMULANG

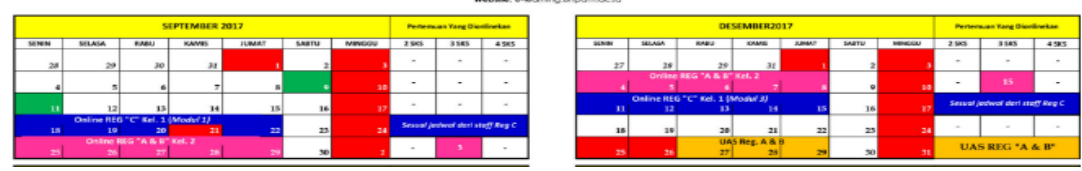

Gambar 1. Tampilan utama e-learning
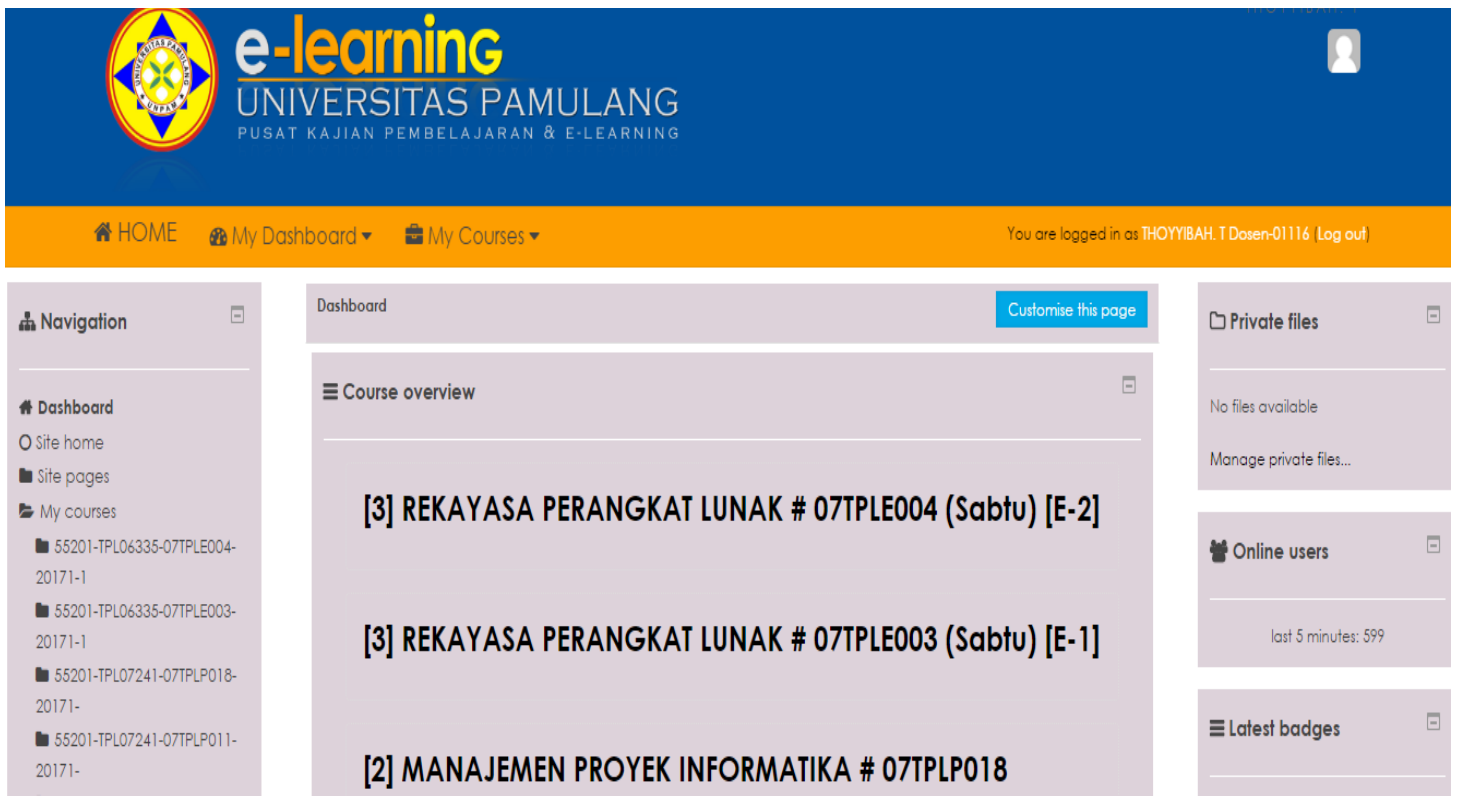

$\square$ Private files

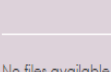

№ files available

Manage private files.

Online users

last 5 minutes: 599

Gambar 2. Tampilan mata kuliah e-learning

PERTEMUAN 1

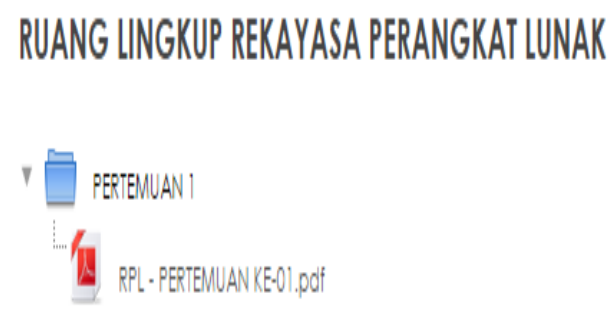

Gambar 3. Tampilan dokumen download 


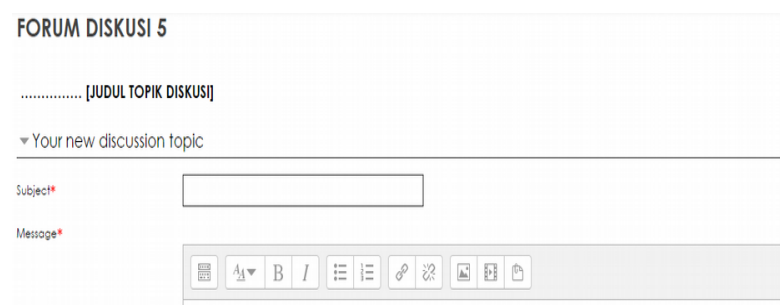

Gambar 4. Tampilan forum diskusi

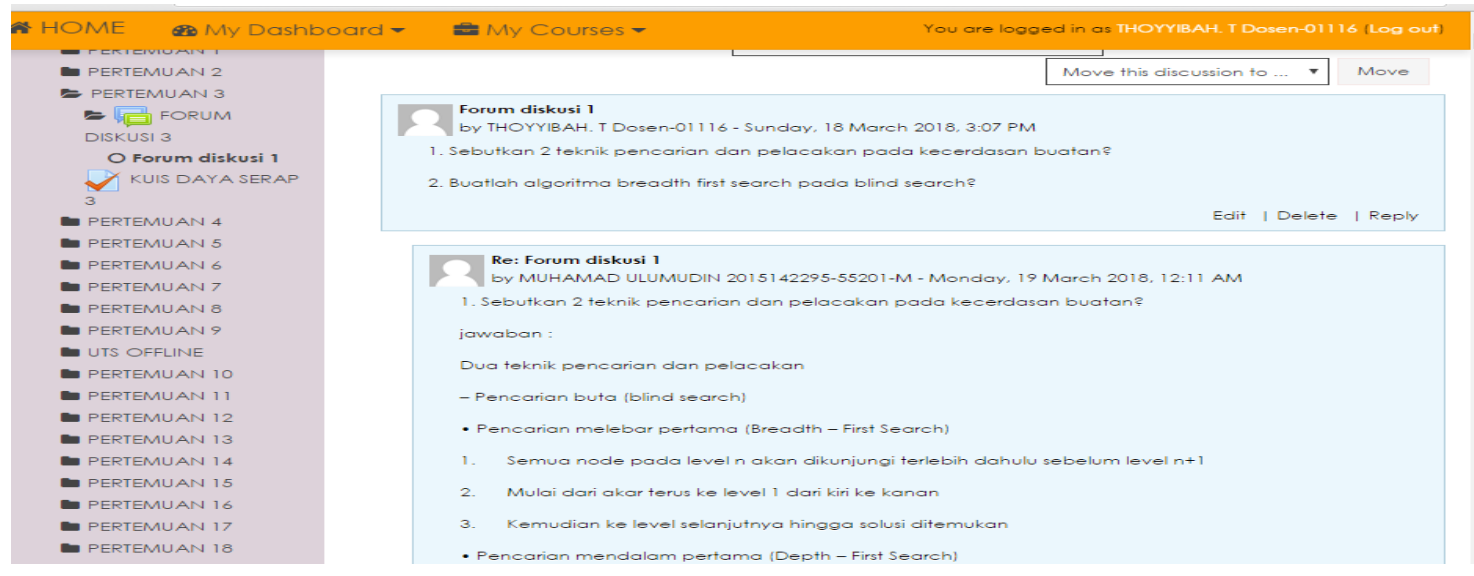

Gambar 5. Tampilan hasil diskusi e-learning

Tabel 8. Hasil kuesioner SUMI terhadap dosen

\begin{tabular}{cccc}
\hline \multirow{2}{*}{ User } & \multicolumn{2}{c}{ Dosen } \\
\cline { 2 - 4 } & Efektifitas & Efisisensi & Kepuasan \\
\hline 1 & 100 & 100 & 90 \\
2 & 95 & 100 & 75 \\
3 & 100 & 100 & 100 \\
4 & 75 & 20 & 30 \\
5 & 100 & 80 & 70 \\
6 & 75 & 95 & 100 \\
7 & 75 & 80 & 75 \\
8 & 100 & 100 & 100 \\
9 & 90 & 60 & 50 \\
10 & 30 & 10 & 60 \\
\hline Median & 92.5 & 87.5 & 75 \\
\hline
\end{tabular}


Tabel 9. Hasil kuesioner SUMI terhadap Mahasiswa

\begin{tabular}{cccc}
\hline User & & Mahasiswa & Kepuasan \\
\cline { 2 - 4 } & Efektifitas & Efisisensi & 70 \\
\hline 1 & 100 & 100 & 80 \\
2 & 70 & 60 & 90 \\
3 & 90 & 90 & 60 \\
4 & 100 & 100 & 60 \\
5 & 95 & 100 & 80 \\
6 & 95 & 60 & 45 \\
7 & 60 & 80 & 70 \\
8 & 45 & 60 & 100 \\
9 & 90 & 90 & 85 \\
10 & 80 & 90 & 75 \\
\hline
\end{tabular}

Tabel 10. Kuesioner SUMI

\begin{tabular}{|c|c|c|c|}
\hline No & Pertanyaan & S $\quad$ TT & TS \\
\hline A & Evaluasi Efektifitas & & \\
\hline A.1 & Pengguna berhasil membuka link e-learning Unpam & & \\
\hline A. 2 & Pengguna dapat memilih mydosen dan myunpam dengan mudah & & \\
\hline A.3 & Pengguna berhasil menginput Username dan password & & \\
\hline A. 4 & Pengguna membaca isi menu e-learning dengan mudah & & \\
\hline A. 5 & Pengguna memahami isi pada setiap icon e-learning Unpam dengan mudah & & \\
\hline A.6 & Pengguna membaca tulisan pada aplikasi e-learning Unpam dengan mudah & & \\
\hline A.7 & Pengguna menemukan menu My Courses dengan mudah & & \\
\hline A.8 & Pengguna dapat memahami mata kuliah yang diinginkan dengan mudah & & \\
\hline A.9 & Pengguna membuka menu Upload atau unduh materi dengan mudah & & \\
\hline A.10 & Pengguna membuka menu untuk diskusi dengan mudah & & \\
\hline
\end{tabular}

Total

\begin{tabular}{ll}
\hline B & Evaluasi Efisiensi \\
\hline B.1 & Pengguna memahami langkah-langkah yang terdapat dalam e-learning \\
B.2 & Panduan dan bantuan dari fasilitator pada e-learning cukup lengkap \\
B.3 & Pengguna memilih menu profil yang diinginkan dengan mudah \\
B.4 & Pengguna memilih mata kuliah yang diinginkan dengan mudah \\
B.5 & Pengguna memilih icon yang benar saat memilih mata kuliah \\
B.6 & Panduan dari fasilitator untuk membuka menu home cukup lengkap \\
B.7 & Panduan dan bantuan dari fasilitator pada menu bahasa cukup lengkap \\
B.8 & Panduan dan bantuan fasilitator pada menu my dashboard cukup lengkap \\
B.9 & Panduan dan bantuan fasilitator pada menu my Courses cukup lengkap \\
B.10 & Panduan dari fasilitator untuk memahami isi semua menu cukup lengkap
\end{tabular}

Total

\begin{tabular}{ll}
\hline C & Evaluasi kepuasan \\
\hline C.1 & Aplikasi e-learning ini mudah digunakan \\
C.2 & Membaca tulisan pada layar e-learning ini sangat mudah \\
C.3 & Komposisi warnanya sesuai \\
C. 4 & Gambar yang ditampilkan menarik \\
C.5 & Bahasa yang digunakan mudah dimengerti \\
C.6 & Istilah-istilah yang digunakan pada aplikasi ini mudah dipahami \\
C.7 & Mahasiswa dan dosen ingin menggunakan aplikasi ini \\
C.8 & Materi pembelajaran untuk Mahasiswa dan dosen mudah dimengerti \\
C.9 & Meningkatkan pengetahuan tentang diskusi online \\
C.10 & Mahasiswa dan dosen terbantu pada mata kuliah yang akan digunakan
\end{tabular}

Total 
Tabel 8 dan Tabel 9 merupakan hasil kuesioner SUMI terhadap dosen dan mahasiswa. Sedangkan Tabel 10 merupakan kuesioner SUMI yang dilakukan oleh dosen dan mahasiswa dengan 30 pertanyaan berupa efektivitas, efisiensi dan kepuasan.

\section{PENUTUP}

Usability Engineering dan evaluasi usability E-Learning UNPAM telah berhasil dilakukan dengan menggunakan kuesioner SUMI (Software Usability Measurment Inventory). Responden yang digunakan pada penelitian ini terdiri dari 20 responden, 10 dosen dan 10 mahasiswa.

Hasil dari perhitungan kuesioner SUMI yaitu $92.5 ; 87.5 ; 75 ; 90 ; 90$ dan 75 . Hasil usability di atas rata-rata artinya usability pada sistem E-learning UNPAM ini sudah masuk kategori baik. Untuk penelitian lebih lanjut perlu mencoba pengujian aplikasi dengan metode yang lain.

\section{DAFTAR PUSTAKA}

[1] Tavangarian, D., Leypold, M.E., Nölting, K., Röser, M., Voigt, D. 2004. Is E-learning the Solution for Individual Learning?. J. E-Learn. EJEL.

[2] Ruiz MD, Jorge G., Mintzer MD, Michael J. \& Leipzig MD, PhD, Rosanne M., 2006. IT in Medical Education. The Impact of E-Learning in Medical Education. Vol.81., No. 3.

[3] Turrahma A, Satyariza EN, Ibrahim A. 2017. Pemanfaatan E-Learning Berbasis LCMS Moodle Dalam Peningkatan Efisiensi Dan Efektivitas Serta Kualitas Media Pembelajaran Siswa di MAN Sakatiga. Jurnal Nasional Pendidikan Teknik Informatika. Volume 6, Nomor 3: 2089-8673.

[4] Riyadi RA, Nur M, Ismayati E. 2015. Pengembangan Perangkat Pembelajaran Berbasis E-Learning Moodle Dengan Model Pengajaran Langsung di SMKN 2 TARAKAN. Jurnal pendidikan vokasi: Teori dan praktek. Vol. 3 No. 1: 2302-285x.

[5] Prayoga SH, Sensuse DI. [Tahun tidak diketahui]. Analisis Usability pada Aplikasi Berbasis Web dengan
Mengadopsi Model Kepuasan Pengguna (User Satisfaction).Jurnal Sistem Informasi MTI-UI. Volume 6 Nomor 1:1412-8896.

[6] Jogiyanto,HM. 2003. Sistem Teknologi Informasi, Yogyakarta: Andi

[7] Gozali F, Lo B. 2012. Pemanfaatan Teknologi Open SourceDalam Perkembangan Proses Belajar Jarak Jauh Di Perguruan Tinggi. Jurnal Nasional Pendidikan Teknik Informatika (JANAPATI). Volume 1, Nomor 1: 2089-8673.

[8] Arief NH, Rakhmawati L. 2015.Pengembangan Media E-Learning Berbasis Learnboost pada Kompetensi Dasar Menerapkan Gerbang Dasar Rangkaian Logika Di SMK Negeri 1 Jetis Mojokerto. Jurnal Pendidikan Teknik Elektro. Volume 04 Nomor 02: 577-582.

[9] Wahyudi I. 2017. Pengembangan Program Pembelajaran Fisika SMA Berbasis E-Learning Dengan Schoology. Jurnal ilmiah pendidikan Fisika Al- Biruni. 187-199:2303-1832

[10] Baihaqi MAW, Rosidi A, Syahdan SA. 2016. Analisis Usability Aplikasi ELearning Di Fakultas Teknik dan Ilmu Komputer Unsiq Wonosobo. Jurnal PPKM III 159-173: 2354869x.

[11] Henriyadi, Mulyati R. 2014. Usability Testing Sistem Informasi Studi Kasus Aplikasi Repository Publikasi Badan Penelitian dan Pengembangan Pertanian. Jurnal Pusat Perpustakaan Dan Penyebaran Teknologi Pertanian.

[12] Veenendaal E. 1998. Questionnaire Based Usability Testing. Conference Proceedings European Software Quality Week; Brussels, November 1998. Valkeenswaard: Improve Quality Services Waalreseweg.

[13] Edwards PJ, Moloney PK, Jacko JA, Sainfort F. 2008. Evaluating Usability Of Commercial Electronic Health Record: A Case Study. Human Computer Studies Journal: 718-728.

[14] Hafit H, Razak FAH, Haron H. 2011. Usability Testing with Children: What We Have Overlooked. Human Computer Interaction Journal:147-150. 
[15] Barendregt W, Bekker MM, Bouwhuis DG, Baauw E. 2006.Identifying Usability and Fun problem in a Computer Game During First Use and After Some Practice. Human Computer Interaction Studies Journal :830-846.

[16] Abran A, Khelifi A, Suryn W. 2003. Usability Meaning and Interpretations in ISO Standards. Software Quality Journal:323-336.

[17] Diah NM, Ismail M, Ahmad S, Dahari MKM. 2010. Usability Testing for Educational Computer Game Using Observation Method. Computer and Mathematical Science Journal. Vol 1: 4244-5651.

[18] Nielsen J. 2012. Usability 101: Introduction to usability. Alertbox. [Internet].[diunduh 2017 Jul 17]. Tersedia pada http://www.nngroup.com/articles/usabili ty-101-introduction-to-usability/

[19] Sianturi SK, Nurhadryani Y, Hermadi I, Khotimah H. 2013. Jurnal Ilmu Komputer Agri-Informatika. Volume 2 No. 2 Hal 83-93: 2089-6016.

[20] Hidayat W, Radis HY, Efendi U. 2014. Penerapan Metode Usability Testing dan Evaluasi Situs Web Pemerintahan Kota Prabumulih. Jurnal Teknik Informatika Universitas Bina Darma Palembang.

[21] Handiwidjojo W, Ernawati L. 2016. Pengukuran Tingkat Ketergunaan (Usability) Sistem Informasi Keuangan Studi Kasus: Duta Wacana Internal Transaction (DuWit). Jurnal Informatika dan Sistem Informasi. Vol. 2 No. 1:2460-1306 